\title{
COVID Pandemic and Impact of Online Teaching Learning process on Teenagers
}

\author{
Prof. Waghadare Dhananjay Shivaji ${ }^{1}$, Prof.Nimase Hanumant Ganpat ${ }^{2}$
}

${ }^{1}$ Assistant Professor Department of English, K.B. P. Mahavidyalaya Pandharpur, Dist. Solapur Maharashtra,

${ }^{2}$ Assistant Professor Department of Marathi, Arts \& Commerce College Pusegaon, Dist Satara Maharashtra

\begin{abstract}
People throughout the world have been facing the crisis of COVID-19 since December 2019. Microbe of pandemic has demolished the structure of traditional educational system; rather there is big question mark of existence before the whole mankind. Online teaching learning became inevitable in this scenario. The purpose of this research paper is to explore the impact of online teaching learning process on teenagers. The screen time of teenagers has increased tremendously; we can say that teenagers hampered lot due to the pandemic. They have been confined unwillingly in their homes, teenagers spend most of their time with laptops and smartphones, and due to this situation they are addicted towards online games and social media. This paper is an attempt to highlight negative impact of the online teaching on teenagers.
\end{abstract}

Key words: Teenagers, COVID-19, Online teaching learning process

\section{1) INTRODUCTION}

In the month of December 2019, the first case of COVID found and it shattered the world's socio- economic scenario of the world and rapidly converted in the pandemic. The field of education affected enormously due to COVID. Rapidly increasing cases compelled government to lockdown due to this situation schools started online education without any preparation. It affects the learning capacity of the students. Especially teenagers the screen-time of the students increased. Teenagers spend most of their time for playing games, social media chatting. Availability of the smartphones internet particularly in the rural and semi urban areas are very poor. In remote areas Wi-Fi facility is not available it creates serious problem for teaching learning process. Impact on health of teenagers is also an essential factor during this pandemic. All these factors can be studied in the following manner.

\section{2) ADDICTION OF ONLINE GAMES OF TEENAGERS}

Due to COVID-19 pandemic the use of smartphones, tab and laptop is inevitable. Children have got addicted towards the online gaming. The survey published in the journal Journal of Addictive Behaviors, Therapy \& Rehabilitation showed that

Among 584 adolescent includes 247 girls (42\%) and 337 boys (58\%). Among the studied 584 adolescents 172 (29\%) adolescents meet 8 out of the 14 criteria and considered as addicted to online games.

Really above mentioned results are shocking, being addicted towards games teenagers rarely focused on their studies .Games like PUB-G, Free Fire, and other games have become integral part of the life of adolescent. The addiction of the online games has increasing since the period of first lockdown in our country. We can say that this is one of the morbid effects of the imposed teaching learning process. This is the biggest challenge before parents and teachers.

As teenagers spend most of their time for online classes and online gaming, health issues found among them are very serious. Psycho-physical impact is found in the teenagers. The survey conducted by students of Lucknow -based Spring Dale College(SDC) Chain of schools it was published in the Times of India According To this survey 58\% students Faced severe health issues like fatigue, anxiety, headache, backache and eyesight trouble and $42 \%$ students faced other similar Physio-Psychological problems. The specimen survey mentioned above gives us the severity of the 


\section{International Advanced Research Journal in Science, Engineering and Technology}

Vol. 8, Issue 9, September 2021

DOI: $10.17148 /$ IARJSET.2021.8924

problem created through the bombarding of Virtual teaching learning .Though there are few educational institutions have implemented blended learning but problem still persists .

\section{Lack Of Communication between adolescents and parents}

Being detached from sports, reading and hobbies students face problem of lack of communication with their parents. Teenagers spend most of their time for online learning and online gaming, they indulge in their fascinated virtual world. They communicate virtually with their virtual friends through social media and online games. It has created severe impact on the familial relationship; face to face communication has become rarely possible between teachers and parents also.

\section{4) PROBLEM OF CONNECTIVITY IN THE REMOTE AREAS}

Connectivity of internet is the major problem in this country. In our country we have geographical diversity, we have remote and hilly areas in such type of areas connectivity of internet is biggest problem, and the students belong to such areas faces severe problem of learning. When we consider the regions of Maharashtra we have area of Vidharbha and Konkan and Some parts of Northern Maharashtra these are remote areas. Due to availability of connectivity rural and partially semi urban students face the difficulty in their learning.as virtual learning cannot be option for traditional learning. It creates hindrance for teenagers for their grasping power.

\section{5) LACK OF PHYSICAL EXERCISES AND SPORTS}

Since March 2020 government imposed strict lockdown, schools are closed so teenagers feel this scenario like confinement. Sports grounds in the schools are strictly restricted for adolescents. Lack of physical activities in teenagers creates serious issue; it creates problems like obesity, laziness and drowsiness in them. Participation in the Cultural programmes and other offline activities became impossible for teenagers.

\section{5) CONCLUSION}

In this paper we have discussed some negative impact of online teaching learning on the teenagers we observe following problems in them during the lockdown

1) Educational loss

2) Health problems

3) Addiction of Online gaming

4) Communication gap

It is the responsibility of schools and parents to overcome above mentioned problems.

\section{REFERENCES}

- $\quad$ All India survey on higher education, 2019

All India Survey on Higher Education (AISHE)

- $\quad$ Ministry of Human Resource Development

Government of India, New Delhi (2019)

Google Scholar

Brandon, 2020

S. Brandon

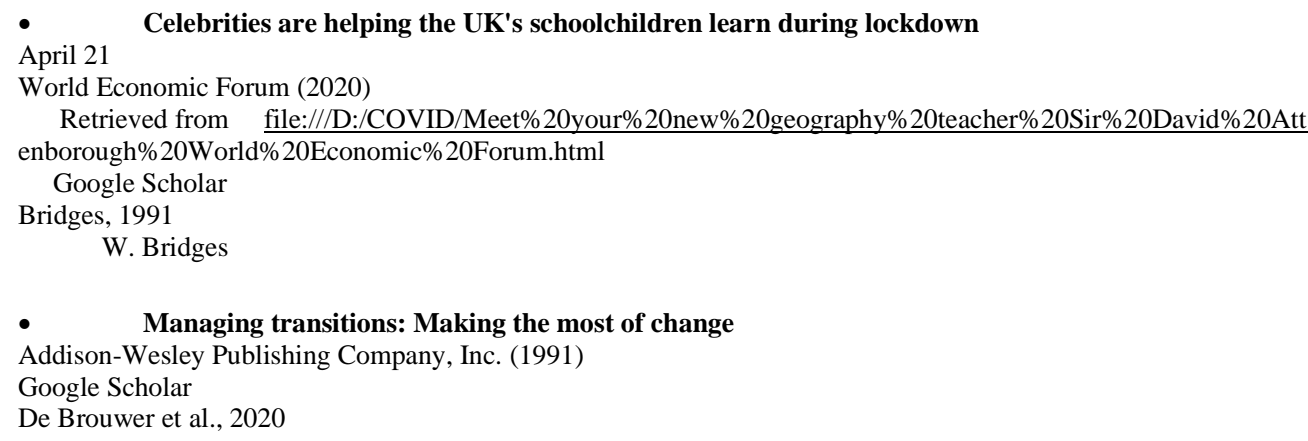




\section{International Advanced Research Journal in Science, Engineering and Technology}

Vol. 8, Issue 9, September 2021

DOI: $10.17148 /$ IARJSET.2021.8924

E. De Brouwer, D. Raimondi, Y. Moreau

- Modeling the COVID-19 outbreaks and the effectiveness of the containment measures adopted across countries medRxiv (2020), pp. 1-8, 10.1101/2020.04.02.20046375do

CrossRefView Record in ScopusGoogle Scholar

DQ Institute, 2019

DQ Institute (2019). Outsmart the Cyber-pandemic: Empower every child with digital intelligence by 2020. Retrieved from

file://D:/COVID/DQEveryChild\%20DQ\%20Institute.html.

Google Scholar

EdSource 2020

EdSource. (2020). Coronavirus: Highlighting strategies for student success. Retrieved from https://edsource.org/topic/coronavirus.

Google Scholar

FutureLeaarn 2020

FutureLeaarn. (March 19, (2020)). COVID-19: The best resources for online teaching during coronavirus. Retrieved from file:///D:/COVID/COVID$19 \% 20$ The $\% 20$ Best $\% 20$ Resources\%20For\%20Online\%20Teaching\%20During\%20Coronavirus\%20-\%20Blog\%20-\%20FutureLearn.html. Google Scholar

- Deschooling society

Harper \& Row, New York (1971)

Google Scholar

Johnson and Christensen, 2012

B. Johnson, L. Christensen

- $\quad$ Educational research: Quantitative, qualitative and mixed approaches

((4 ed.)), Sage Publications, Inc., Thousand Oaks, California (2012)

Google Scholar

Khachfe et al., 2020

H.H. Khachfe, M. Chahrour, J. Sammouri, H. Salhab, B.E. Makki, M. Fares

- An Epidemiological Study on COVID-19: A Rapidly Spreading Disease

Cureus, 12 (3) (2020), 10.7759/cureus.7313

doi: E7313

Google Scholar

Lederman, D. (2020))(March 18,. Will shift to remote teaching be boon or bane for online learning? Inside Higher Ed. Retrieved from file:///D:/COVID/Most\%20teaching\%20is\%20going\%20remote.\%20Will\%20that\%20help\%20or\%20hurt\%20online\%20learning.html. Google Scholar

K. Lewin

- Group decision and social change

E.E. Maccoby, T.M. Newcomb, E.L. Hartley (Eds.), Readings in social psychology, Rinehart \& Winston, Holt (1958), pp. 197-211

View Record in ScopusGoogle Scholar

- $\quad$ Educating despite the Covid-19 outbreak: Lessons from Singapore

March 20

The World University Rankings (2020)

Retrieved from

https://www.timeshighereducation.com/blog/educating-despite-covid-19-outbreak-lessons-singapore\#\%20

Google Scholar

J. Martinez

- $\quad$ Take this pandemic moment to improve education

EduSource (2020)

Retrieved from

https://edsource.org/2020/take-this-pandemic-moment-to-improve-education/633500

Google Scholar

National School Choice Week. (2020). Free online resources for schools shifting online during coronavirus pandemic. Retrieved from file:///D:/COVID/National\%20School\%20Choice\%20Week.html. 